Gut, 1973, 14, 433-437

\title{
A possible relationship to treatment between hepatitis-associated antigen and chronic persistent hepatitis in Hodgkin's disease
}

\author{
M. J. GRANGE, S. ERLINGER¹, F. TEILlET, N. SCHLEGEL, J. BARGE, AND \\ C. DEGOTT \\ From Unité de recherches de physiopathologie hépatique, Hôpital Beaujon, Clichy, Groupe d'études sur la \\ maladie de Hodgkin, Hôpital Saint-Louis, Paris, Service central d'immunologie-hématologie, Hôpital \\ Beaujon, Clichy, and Laboratoire central d'anatomie pathologique, Hôpital Beaujon, Clichy, France
}

SUMMARY Hepatitis-associated (Australia) antigen (HAA) was detected in the sera of $16(50 \%)$ of 33 patients with Hodgkin's disease; all of these patients had received the same treatment for approximately two years, and they had been in complete remission for at least two years. The HAA-positive patients had significantly higher levels of serum SGPT and significantly lower bromsulphalein clearance than the HAA-negative patients. Histological changes compatible with a diagnosis of chronic persistent hepatitis were found in the livers of 12 of the $16 \mathrm{HAA}$-positive patients and in five of the 17 HAA-negative patients $(P<0.05)$. In 128 patients with Hodgkin's disease who had received various forms of treatment and who were studied at various stages of remission, HAA was found in the sera of $42(33 \%)$. Tests for HAA repeated four months later in positive reactors of both groups showed persisting antigenaemia. Hepatitis-associated antigen was not present in the sera of any of 36 patients with Hodgkin's disease studied when the diagnosis was first made and before treatment had begun. These observations suggest that persistence of HAA and the presence of chronic persistent hepatitis were more likely to be related to the treatment the patients had received than to the disease itself.

Australia antigen (serum hepatitis (SH) antigen, also named hepatitis B antigen (HB Ag) and hepatitisassociated antigen (HAA)) has been found in the sera of patients with acute hepatitis and certain forms of chronic hepatitis (Blumberg, Gerstley, Hungerford, London, and Sutnick, 1967a; Prince, 1968; London, Sutnick, and Blumberg, 1969b; Prince, Hargrove, and Jeffries, 1969; Shulman, 1970; Blumberg, Sutnick, and London, 1968). It has also been identified in patients with Down's syndrome (mongolism) (Blumberg et al, 1967a; Blumberg et $a l, 1968$; Sutnick, London, Gerstley, Cronlund, and Blumberg, 1968; Shulman, 1970), lepromatous leprosy (Blumberg, Melartin, Lechat, and Guinto, 1967b; Blumberg et al, 1968; Blumberg and Melartin, 1970; Shulman, 1970), chronic renal disease (patients undergoing haemodialysis)(London,

'Please address requests for reprints to: Dr Serge Erlinger, Unité de recherches de physiopathologie hépatique, Hôpital Beaujon, F 92110 Clichy, France.

Received for publication 29 March 1973.
Di Figlia, Sutnik, and Blumberg, 1969a; Turner and White, 1969; Shulman, 1970; Leski, Grivaux, and Courouce-Pauty, 1971), and certain forms of leukaemia (Blumberg, Alter, and Visnich, 1965; Blumberg et al, 1967; Blumberg et al, 1968; Sutnick, London, Blumberg, Yankee, Gerstley, and Millman, 1970; Sutnick, Levine, London, and Blumberg, 1971); in most of these diseases it has been shown to be associated with anomalies of liver structure and function which are compatible with the presence of chronic hepatitis (Blumberg et al, 1968; Sutnick et al, 1968; London et al, 1969b; Shulman, 1970; Blumberg et al, 1970; Blumberg, Sutnick, and London, 1970). Finally, HAA occurs in a small percentage of apparently normal subjects in some populations (Blumberg et al, 1965; Blumberg et al, 1968; London et al, 1969b).

The purpose of this work was to study the occurrence of HAA in Hodgkin's disease, its relation to treatment, and its pathological significance. In previous studies of the frequency of HAA in this 
condition (Sutnick et al, 1970; Sutnick et al, 1971) liver histology and function were not investigated and treatment, other than blood transfusion, was not taken into account.

\section{Patients and Methods}

Tests for HAA were performed on the sera of 33 patients (group 1) with Hodgkin's disease, all of whom had had treatment consisting of chlormethine hydrochloride $(0.1 \mathrm{mg}$ per $\mathrm{kg}$ body weight daily for five days), radiotherapy by Kaplan's method (Kaplan, 1962) (4000 rads in four weeks), and maintenance chemotherapy with vinblastine (vincaleucoblastine sulphate) $(10 \mathrm{mg}$ per month for at least two years). All had been in complete remission for a minimum of two years. Tests for HAA were also performed on the sera of 128 patients (group 2) with Hodgkin's disease who had received either the same treatment as group 1 or combination chemotherapy (Jacquillat, Weil, Desprez-Curély, Tanzer, Gemon, Blouin, Teillet, Delobel, Nikdjou, Loisel, Boiron, and Bernard, 1971); some of these patients were in incomplete remission, others had been in complete remission for less than two years. Finally, the sera of 36 patients (group 3) with newly diagnosed Hodgkin's disease, who had had no treatment, were tested for hepatitis-associated antigen. The mean intervals between the appearance of first symptoms and testing for HAA were 46 months (range 18 months to six years) in group 1, 34 months (range three months to $71 / 2$ years) in group 2 , and 15 months (range one month to seven years) in group 3. Tests for HAA were repeated four months later in most of the patients whose sera gave a positive reaction on the first occasion.
In all cases the diagnosis of Hodgkin's disease was histologically proven. No patient showed clinical evidence of liver disease and none had a history of antecedent hepatitis. All injections had been given with disposable syringes. No patient had had blood transfusion.

All sera were tested by immunodiffusion (Prince, 1968) and counterimmunoelectrophoresis (Alter, Holland, and Purcell, 1971). The following additional investigations were performed in the patients of group 1: determination of serum glutamic pyruvic transaminase (SGPT) activity (Reitman and Frankel, 1957, modified), bromsulphalein (BSP) fractional clearance (Fauvert, Weber, and Benhamou, 1964), serum alkaline phosphatase activity (Bessey, Lowry, and Brock, 1946), and serum bilirubin level (Weber and Schalm, 1962); serum protein electrophoresis; laparoscopy; and needle biopsy of liver by the Menghini technique. Tests for immunological impairment were not performed.

\section{Results}

Hepatitis-associated antigen was detected in 16 $(50 \%)$ of the patients of group 1 , in $42(33 \%)$ of those of group 2, and in none of group 3. Tests for HAA repeated four months later in the sera of 14 of the 16 HAA-positive patients of group 1 and of 29 of the 42 HAA-positive patients of group 2 still gave positive results.

In group 1 (table) sex and age distribution and stage of the disease did not differ in the HAAnegative and the HAA-positive patients. Serum SGPT levels (fig 1) were significantly higher and BSP clearance (fig 2) was significantly lower in HAA-positive than in HAA-negative patients, but

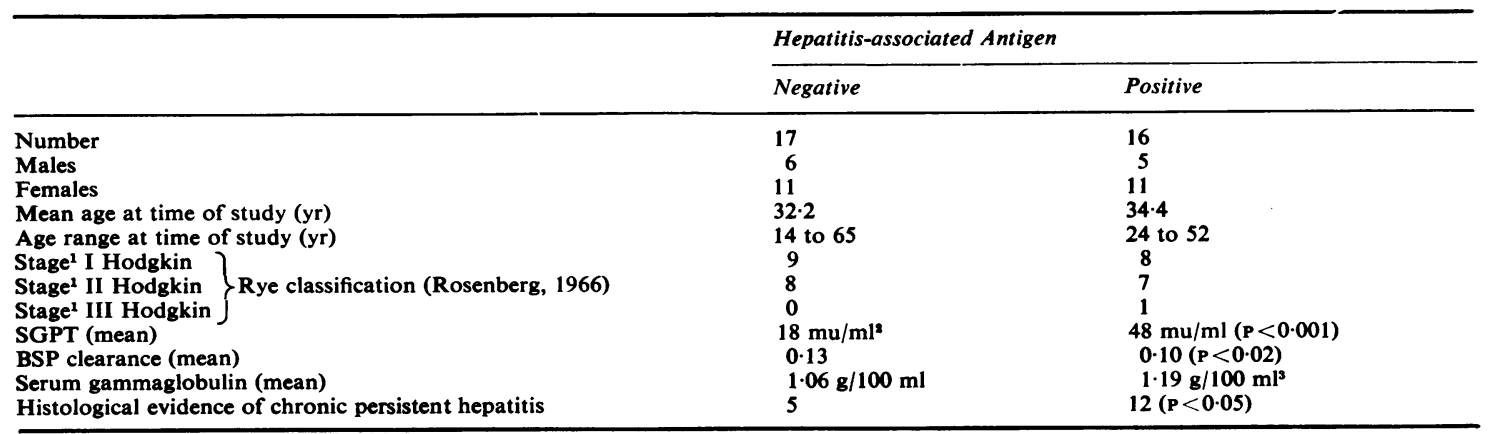

Table Incidence of hepatitis-associated antigen in 33 patients who had received treatment for Hodgkin's disease (group 1)

${ }^{1}$ At time of inception of treatment.

${ }^{2} \mathrm{mu} / \mathrm{ml}=$ milliunits per millilitre.

sDifference not statistically significant. 


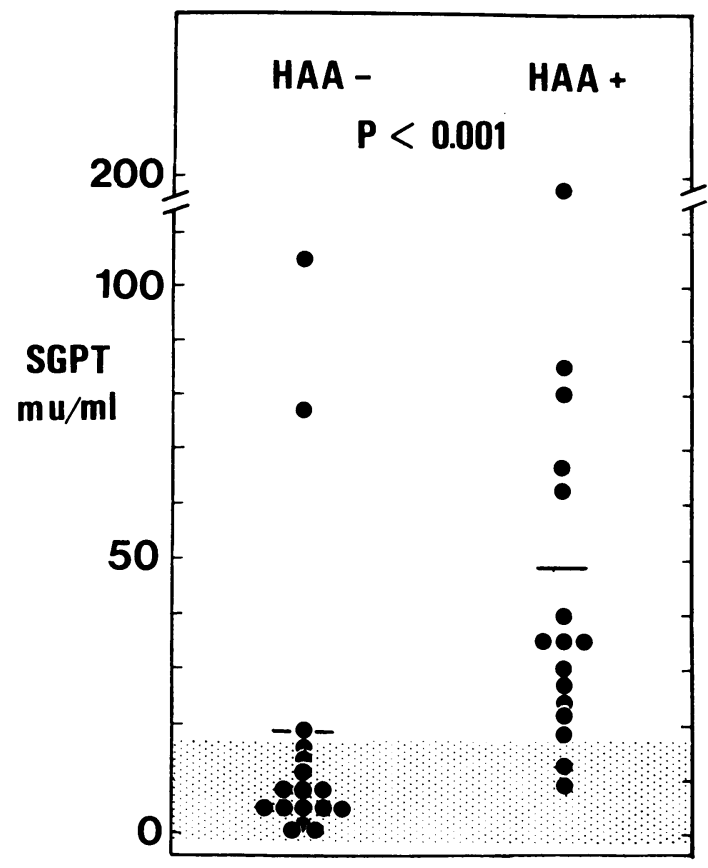

Fig 1 The SGPT levels in 33 patients with treated Hodgkin's disease: 17 HAA-negative patients on left; 16 HAA-positive patients on right. Horizonatal bars $=$ means. Shaded area $=$ normal range.

no significant difference in gamma globulin levels (fig 3) was found. Serum alkaline phosphatase activity and serum bilirubin concentration were within normal limits in all patients.

Histological lesions compatible with a diagnosis of chronic persistent hepatitis (de Groote, Desmet, Gedigk, Korb, Popper, Poulsen, Scheuer, Schmid, Thaler, Uehlinger, and Wepler, 1968) were demonstrated in the livers of 12 of the 16 HAA-positive patients and of five of the 17 HAA-negative patients $(P<0.05)$. A typical lesion is shown in figure 4 . The specific hepatic changes of Hodgkin's disease were not detected in any liver. The surface of the liver viewed at laparoscopy was smooth in every case.

\section{Discussion}

Thus, a significantly higher frequency of HAA was found in patients with Hodgkin's disease who had received treatment than in patients who had received no treatment. Persistence of HAA positivity four months later indicated that the antigenaemia was not transient.

One possible explanation for the presence of HAA is the longer mean interval between the first symptoms

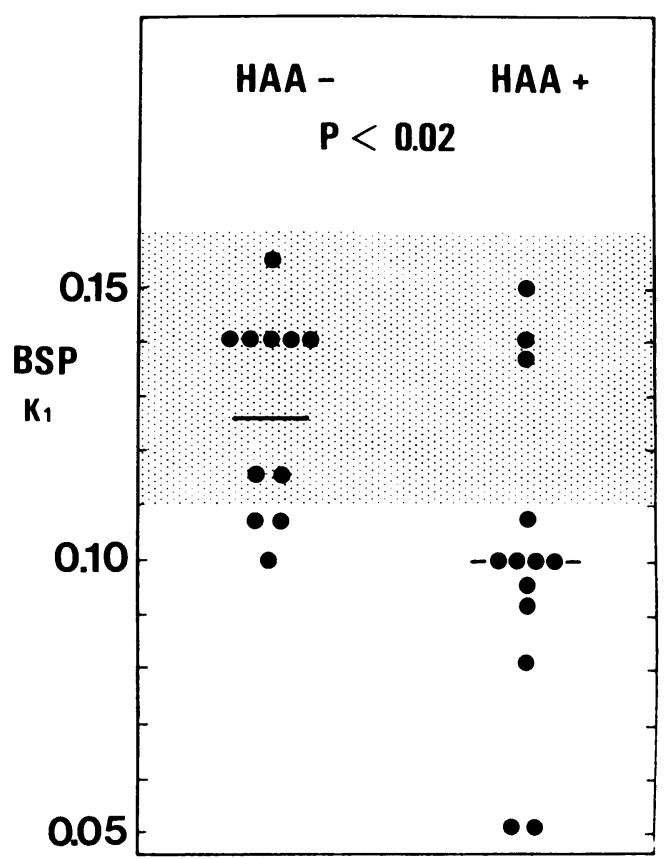

Fig 2 Bromsulphalein fractional clearance $\left(K_{1}\right)$ in 24 patients with treated Hodgkin's disease: $11 \mathrm{HAA}$ negative patients on left; $13 \mathrm{HAA}$-positive patients on right. Horizontal bars $=$ means. Shaded area $=$ normal range.

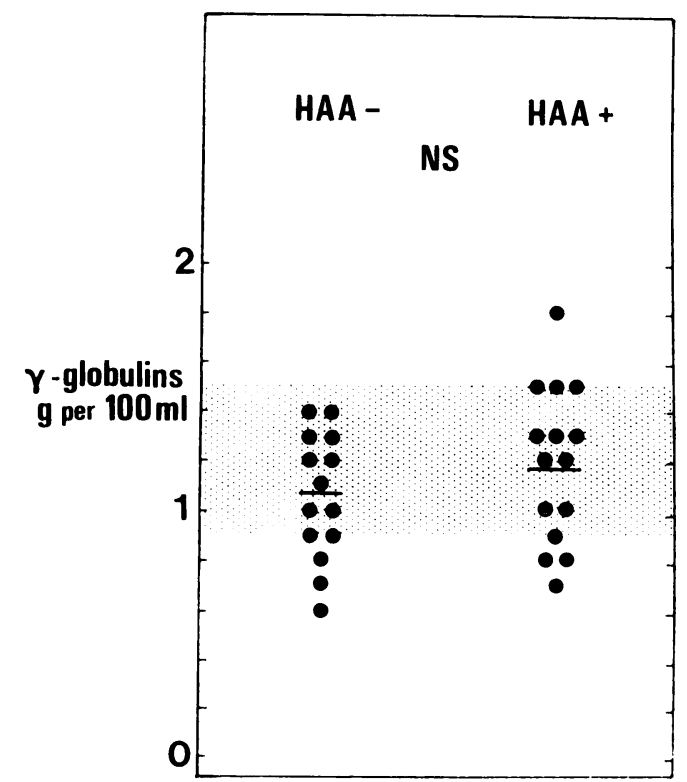

Fig 3 Gamma globulin levels in 29 patients with treated Hodgkin's disease: 14 HAA-negative patients on left; 15 HAA-positive patients on right. Horizontal bars $=$ means. Shaded area $=$ normal range. $N S=$ not significant. 


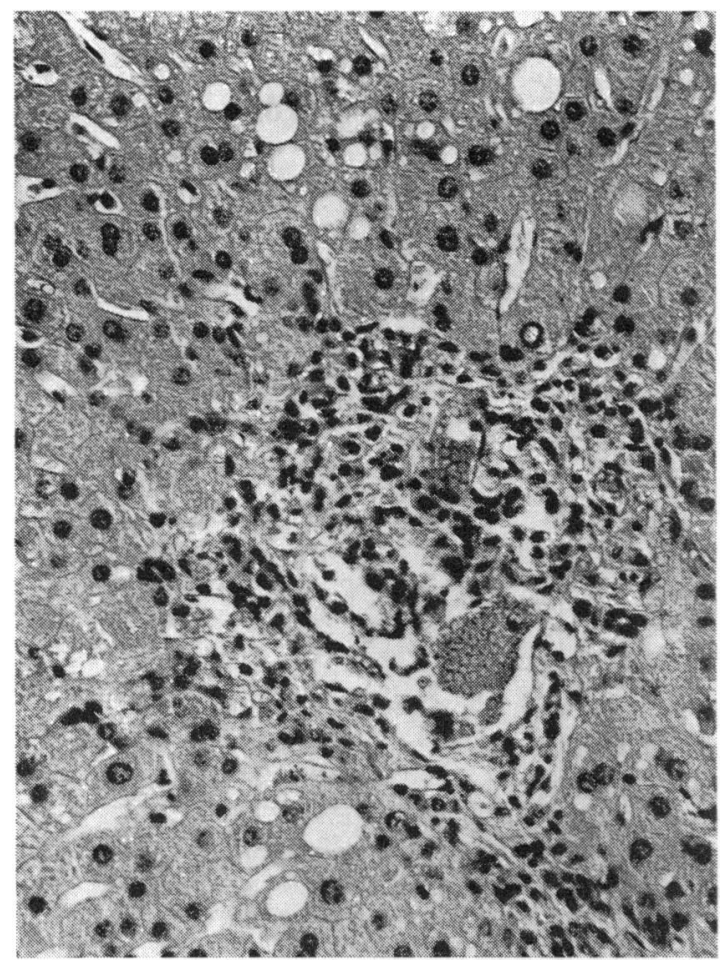

Fig 4 Liver of an HAA-positive patient with treated Hodgkin's disease. The changes are characteristic of chronic persistent hepatitis; inflammatory cells, mainly mononuclears, in a portal canal; no fibrosis, minimal hepatocellular changes.

and the test for the antigen in the treated groups (46 and 34 months) than in the untreated group (15 months). Two points are against this explanation. (1) Hepatitis-associated (Australia) antigen was not found in those of the untreated patients in whom the interval was as long as seven years. (2) The patients of group 1, in whom the incidence of HAA was highest, had shown no clinical or laboratory evidence of Hodgkin's disease for at least two years preceding the tests, a fact which suggests that the disease was no longer present when the tests were performed.

A more plausible hypothesis is that the acquisition and the persistence of HAA were the result of treatment-induced impairment in cell-mediated immune response. Both radiotherapy (Hulse, 1959) and vinblastine (Aisenberg, 1963) are known to exert an immunosuppressant action. It has been suggested that immunosuppressant therapy, corticosteroids for example, can lead to persistence of HAA and associated liver damage, presumably by suppressing $T$ (thymus-dependent)-lymphocyte function (Dudley,
Fox, and Sherlock, 1972; Giustino, Dudley, and Sherlock, 1972; Dudley, Giustino, and Sherlock, 1972). Impairment of the immune mechanism has been proposed as a cause of persistent Australia antigenaemia and of anomalies suggestive of chronic persistent hepatitis in Down's syndrome (Blumberg et al, 1968; Sutnick et al, 1968; Blumberg et al, 1970), lepromatous leprosy (Blumberg et al, 1968; Blumberg et al, 1970; Blumberg et al, 1970), chronic renal disease (London et al, 1969a; Turner and White, 1969; Blumberg et al, 1970; Leski et al, 1971), and leukaemia (Blumberg et al, 1968). Two previous observations, however, are difficult to reconcile with this hypothesis. (1) Depressed cellular immunity has in fact been demonstrated in Hodgkin's disease (Aisenberg, 1966; Kelly, and Good, 1968) but in the early untreated Hodgkin's case, that is, the case in which we found no hepatitis-associated (Australia) antigen. (2) In an investigation of the relationship of HAA to various forms of therapy in 512 leukaemia patients (Sutnick et al, 1970) HAA was not found to be associated with chemotherapy or radiotherapy, although there was a significant association with blood transfusion.

The pathological significance of persistence of HAA in the serum in diseases other than established acute and chronic hepatitis is as yet undetermined. The statistically significant association, in the patients of group 1, between the presence of HAA on the one hand and raised SGPT levels and the histological changes of chronic persistent hepatitis on the other, suggests that Australia antigenaemia signals the presence of chronic hepatitis; similar associations have already been reported (Blumberg et al, 1968; Sutnick et al, 1968; London et al, 1969b; Blumberg et al, 1970; Payet, Ménaché, Saimot, Schlegel, Eyquem, and Coulaud, 1971). The SGPT levels found in the HAA-positive patients of group 1 are of the order found in chronic hepatitis and chronic haemodialysis patients (Blumberg, Sutnick, London, and Millman, 1972). In contrast, those workers found that SGPT values in patients with Down's syndrome or with lepromatous leprosy were generally within the normal range, although higher in HAA-positive than in HAA-negative subjects.

The smoothness of the livers noted at laparoscopy in our cases proved that the condition was not cirrhotic.

It may be that some of the non-specific hepatic changes, consisting chiefly in mononuclear cell infiltration of the portal canals, previously noted in Hodgkin's disease (Bagley, Roth, Thomas, and Devita, 1972), were in fact due to chronic persistent hepatitis.

Tests for cell-mediated immunity are being performed at present in the patients of this series. In 
addition, in an attempt to define the influence of chemotherapy in the acquisition of HAA and in the development of chronic hepatitis in Hodgkin's disease, patients who have been given initial irradiation but no maintenance chemotherapy with vinblastine are now being investigated.

\section{References}

Aisenberg, A. C. (1963). Suppression of immune response by 'vincristine' and 'vinblastine'. Nature (Lond.), 200, 484.

Aisenberg, A. C. (1966). Immunologic status of Hodgkin's disease. Cancer (Philad.), 19, 385-394.

Alter, H. J., Holland, P. V., and Purcell, R. H. (1971). Counterelectrophoresis for detection of hepatitis-associated antigen: methodology and comparison with gel diffusion and complement fixation. J. Lab. clin. Med., 77, 1000-1010.

Bagley, C. M., Jr., Roth, J. A., Thomas, L. B., and Devita, V. T., Jr. (1972). Liver biopsy in Hodgkin's disease. Clinicopathologic correlations in 127 patients. Ann. intern. Med., 76, 219-225.

Bessey, O. A., Lowry, O. H., and Brock, M. J. (1946). A method for the rapid determination of alkaline phosphatase with five cubic millimeters of serum. J. biol. Chem., 164, 321-329.

Blumberg, B. S., Alter, H. J., and Visnich, S. (1965). A 'new' antigen in leukemia sera. J. Amer. med. Ass., 191, 541-546.

Blumberg, B. S., Gerstley, B. J. S., Hungerford, D. A., London, W. T., and Sutnick, A. I. (1967a). A serum antigen (Australia antigen) in Down's syndrome, leukemia and hepatitis. Ann. intern. Med., 66, 924-931.

Blumberg, B. S., and Melartin, L. (1970). Australia antigen and hepatitis: studies in asymptomatic people and lepromatous leprosy patient. Arch. intern. Med., 125, 287-292.

Blumberg, B. S., Melartin, L., Lechat, M., and Guinto, R. S. (1967b). Association between lepromatous leprosy and Australia antigen. Lancet, 2, 173-176.

Blumberg, B. S., Sutnick, A. I., and London, W. T. (1968). Hepatitis and leukemia: their relation to Australia antigen. Bull. N.Y. Acad. Med., 44, 1566-1586.

Blumberg, B. S., Sutnick, A. I., and London, W. T. (1970). Australia antigen as a hepatitis virus. Amer. J. Med., 48, 1-8.

Blumberg, B. S., Sutnick, A. I., London, W. T., and Millman, I. (1972). Australia Antigen and Hepatitis, p. 49. Butterworths, London.

De Groote, J., Desmet, V. J., Gedigk, P., Korb, G., Popper, H., Poulsen, H., Scheuer, P. J., Schmid, M., Thaler, H., Uehlinger, E., and Wepler, W. (1968). A classification of chronic hepatitis. Lancet, 2, 626-628.

Dudley, F. J., Fox, R. A., and Sherlock, S. (1972). Cellular immunity and hepatitis-associated, Australia antigen liver disease. Lancet, 1, 723-726.

Dudley, F. J., Giustino, V., and Sherlock, S. (1972). Cell-mediated immunity in patients positive for hepatitis-associated antigen. Brit. med. J., 4, 754-756.

Fauvert, R. E., Weber, J., and Benhamou, J. P. (1964). Bromsulphalein fractional clearance. Biochem. Clin., 3, 39-45.
Giustino, V., Dudley, F. J., and Sherlock, S. (1972). Thymus-dependent lymphocyte function in patients with hepatitis-associated antigen. Lancet, 2, 850-853.

Hulse, E. V. (1959). Lymphocyte depletion of the blood and bone marrow of the irradiated rat: a quantitative study. Brit. $J$. Haemat., 5, 278-283.

Jacquillat, C., Weil, M., Desprez-Curély, J. P., Tanzer, J., Gemon, M. F., Blouin, R., Teillet, F., Delobel, J., Nikdjou, Loisel, J. P., Boiron, M., and Bernard, J. (1971). Chimiothérapie de la maladie de Hodgkin par les associations therapeutiques. Bull. Cancer, 58, 221-234.

Kaplan, H. S. (1962). The radical radiotherapy of regionally localized Hodgkin's disease. Radiology, 78, 553-561 and 569.

Kelly, W. D., and Good, R. A. (1968). Immunologic deficiency in Hodgkin's disease. In Immunologic Deficiency Diseases in Man (birth defects original article series, vol. 4, no. 1), pp. 349-356. National Foundation, New York.

Leski, M., Grivaux, G., and Courouce-Pauty, A. M. (1971). L'antigène Australie dans une unité d'hémodialyse périodique et de transplantation rénale. Presse méd., 79, 391-394.

London, W. T., DiFiglia, M., Sutnick, A. I., and Blumberg, D. S. (1969a). An epidemic of hepatitis in a chronic-hemodialysis unit: Australia antigen and differences in host response. New Engl. J. Med., 281, 571-578.

London, W. T., Sutnick, A. I., and Blumberg, B. S. (1969b). Australia antigen and acute viral hepatitis. Ann. intern. Med., 70, 55-59.

Payet, M., Ménaché, D., Saimot, G., Schlegel, N., Eyquem, P., and Coulaud, J. P. (1971). L'antigène Australie chez l'Africain. Presse méd., 79, 2359-2361.

Prince, A. M. (1968). An antigen detected in the blood during the incubation period of serum hepatitis. Proc. nat. Acad. Sci. (Wash.), 60, 814-821.

Prince, A. M., Hargrove, R. L., and Jeffries, G. H. (1969). The role of serum hepatitis virus in chronic liver disease. Trans. Ass. Amer. Phycns, 82, 265-277.

Reitman, S., and Frankel, S. (1957). A colorimetric method for the determination of serum glutamic oxalacetic and glutamic pyruvic transaminases. Amer. J. clin. Path., 28, 56-63.

Rosenberg, S. A. (1966). Report of the Committee on the staging of Hodgkin's disease. Cancer Res., 26, 1310.

Shulman, N. R. (1970). Hepatitis associated antigen. Amer. J. Med., 49, 669-692.

Sutnick, A. I., Levine, P. H., London, W. T., and Blumberg, B. S. (1971). Frequency of Australia antigen in patients with leukaemia in different countries. Lancet, 1, 1200-1202.

Sutnick, A. I., London, W. T., Blumberg, B. S., Yankee, R. A., Gerstley, B. J. S., and Millman, I. (1970). Australia antigen (a hepatitis-associated antigen) in leukemia. J. nat. Cancer Inst., 44, 1241-1249.

Sutnick, A. I., London, W. T., Gerstley, B. J. S., Cronlund, M. M., and Blumberg, B. S. (1968). Anicteric hepatitis associated with Australia antigen: occurrence in patients with Down's syndrome. J. Amer. med. Ass., 205, 670-674.

Turner, G. C., and White, G. B. B. (1969). S.H. antigen in haemodialysis-associated hepatitis. Lancet, 2, 121-125.

Weber, A. P., and Schalm, L. (1962). Quantitative separation and determination of bilirubin and conjugated bilirubin in human serum. Clin. chim. Acta, 7, 805-810. 